\title{
Agonistic and antagonistic estrogens in licorice root (Glycyrrhiza glabra)
}

\author{
Rudy Simons • Jean-Paul Vincken • Loes A. M. Mol • Susan A. M. The • \\ Toine F. H. Bovee • Teus J. C. Luijendijk • Marian A. Verbruggen • Harry Gruppen
}

Received: 16 March 2011 / Revised: 21 April 2011 / Accepted: 25 April 2011 /Published online: 15 May 2011

(C) The Author(s) 2011. This article is published with open access at Springerlink.com

\begin{abstract}
The roots of licorice (Glycyrrhiza glabra) are a rich source of flavonoids, in particular, prenylated flavonoids, such as the isoflavan glabridin and the isoflavene glabrene. Fractionation of an ethyl acetate extract from licorice root by centrifugal partitioning chromatography yielded 51 fractions, which were characterized by liquid chromatography-mass spectrometry and screened for activity in yeast estrogen bioassays. One third of the fractions displayed estrogenic activity towards either one or both estrogen receptors (ERs; ER $\alpha$ and ER $\beta$ ). Glabrene-rich fractions displayed an estrogenic response, predominantly to the ER $\alpha$. Surprisingly, glabridin did not exert agonistic activity to both ER subtypes. Several fractions displayed higher responses than the maximum response obtained with the reference compound, the natural hormone $17 \beta$-estradiol
\end{abstract}

Electronic supplementary material The online version of this article (doi:10.1007/s00216-011-5061-9) contains supplementary material, which is available to authorized users.

R. Simons · J.-P. Vincken • L. A. M. Mol • S. A. M. The •

H. Gruppen $(\bowtie)$

Laboratory of Food Chemistry, Wageningen University,

P.O. Box 8129, 6700 EV, Wageningen, The Netherlands

e-mail: harry.gruppen@wur.nl

R. Simons $\cdot$ M. A. Verbruggen

Frutarom Netherlands BV,

Landjuweel 5 ,

3905 PE, Veenendaal, The Netherlands

T. F. H. Bovee

Department of Safety and Health,

RIKILT-Institute of Food Safety,

P.O. Box 230, 6700 AE, Wageningen, The Netherlands

T. J. C. Luijendijk

PRISNA bv,

Einsteinweg 55,

2333 CC, Leiden, The Netherlands
$\left(E_{2}\right)$. The estrogenic activities of all fractions, including this so-called superinduction, were clearly ER-mediated, as the estrogenic response was inhibited by $20-60 \%$ by known ER antagonists, and no activity was found in yeast cells that did not express the ER $\alpha$ or ER $\beta$ subtype. Prolonged exposure of the yeast to the estrogenic fractions that showed superinduction did, contrary to $E_{2}$, not result in a decrease of the fluorescent response. Therefore, the superinduction was most likely the result of stabilization of the ER, yeast-enhanced green fluorescent protein, or a combination of both. Most fractions displaying superinduction were rich in flavonoids with single prenylation. Glabridin displayed ER $\alpha$-selective antagonism, similar to the $\mathrm{ER} \alpha$-selective antagonist $\mathrm{RU}$ 58668. Whereas glabridin was able to reduce the estrogenic response of $E_{2}$ by approximately $80 \%$ at $6 \times$ $10^{-6} \mathrm{M}$, glabrene-rich fractions only exhibited agonistic responses, preferentially on ER $\alpha$.

Keywords Prenylation · Isoflavonoids · Licorice ·

Estrogenicity $\cdot$ Antagonism $\cdot$ Superinduction

\section{Introduction}

Flavonoids are a broad class of phenolic compounds mainly found in plants with a wide range of bioactivities [1]. Prenylated flavonoids, in particular, are of interest with respect to bioactivity, as prenylation is considered to modulate the responses towards the estrogen receptor $[1,2]$. Prenylsubstitution of the flavonoid subclasses flavones, flavanones, and flavonols has been linked to an increased affinity to the estrogen receptor $\alpha(E R \alpha)$ [3-5], e.g., prenylation of the eight-position of the flavanone naringenin results in a 200 1,000 higher estrogenic activity [6]. Furthermore, the 
prenylation of isoflavonoids has been suggested to induce antagonistic activity when binding to $\operatorname{ER} \alpha[5,7,8]$.

Licorice roots (Glycyrrhiza glabra) are a rich source of prenylated flavonoids. They might offer opportunities for the development of new food supplements related to, e.g., the alleviation of osteoporosis and menopausal complaints [9]. Approximately 75 prenylated flavonoids have been identified, mainly belonging to isoflavans, isoflavenes, and flavanones $[10,11]$.

Previous studies have shown that licorice root extracts have estrogenic activity towards the $\operatorname{ER} \alpha$ and $\operatorname{ER} \beta[12$, 13]. The key estrogenic compounds isolated from G. glabra were identified as glabrene and glabridin, both prenylated isoflavonoids $[14,15]$. The estrogen-like activities of both compounds have been established by means of competitive ligand binding assays, in vitro cell assays, and in vivo animal models [16, 17]. It has been demonstrated that glabrene and glabridin bind to the $\mathrm{ER}$ with $\mathrm{EC}_{50}$ values of $5 \times 10^{-5} \mathrm{M}$ and $5 \times 10^{-6} \mathrm{M}$, respectively. These values were obtained using an MCF-7 cell line that is known to express the ER $\alpha$ type mainly (no detectable ER $\beta$ amounts on the protein level), indicating that both compounds were agonists $[18,19]$. However, the specific estrogenic potencies of glabrene and glabridin towards $\operatorname{ER} \alpha$ and $\operatorname{ER} \beta$ and their potential antagonistic activities have not yet been investigated. Such information is vital for understanding their specific estrogenic activity in the human body.

The aim of the present study was to determine the predominant estrogenic compounds of licorice roots that are active on both ER subtypes and investigate their agonistic and antagonistic potencies. To this end, fractions of a licorice root extract obtained by centrifugal partitioning chromatography were characterized by liquid chromatography-mass spectrometry (LC-MS) and subsequently screened for (anti)estrogenic activity using yeast estrogen bioassays.

\section{Experimental section}

Materials The roots of G. glabra, collected in Afghanistan, were provided by Frutarom US (North Bergen, NJ, USA). Estradiol was purchased from Sigma Aldrich (St. Louis, MO, USA) and glabridin from Wako Chemicals $\mathrm{GmbH}$ (Neuss, Germany). RU 58668 and $R, R$-diethyl-THC $(R, R$ THC) were purchased from Tocris Bioscience (Bristol, UK). Analytical reagent-grade $n$-hexane, acetone, and absolute ethanol and ultra-LC-MS grade acetonitrile were purchased from Biosolve BV (Valkenswaard, The Netherlands). Water was prepared using a Milli-Q water purification system (Millipore, Billerica, MA, USA). Dimethylsulfoxide (DMSO) and all other chemicals were purchased from Merck (Darmstadt, Germany).
Preparation of licorice extract The roots were milled with a ZM 200 Retsch Ultra Centrifugal Mill (Haan, Germany) using a 1-mm sieve. The root powder was extracted with ethyl acetate (EA) in a ratio of 1 to $25(w / w)$ for $2 \mathrm{~h}$ at $40{ }^{\circ} \mathrm{C}$ under continuous stirring. The extract was obtained by pressing the mixture with a Fischer Maschinenbau hydraulic press type HP 5M (Gemmrigheim, Germany) under 40 bar for $1 \mathrm{~h}$. The dried extract was obtained after evaporation of the EA under reduced pressure at $40{ }^{\circ} \mathrm{C}$.

CPC fractionation of licorice extract Centrifugal partitioning chromatography (CPC) was performed using a thermostated Kromaton FCPC machine (Angers, France) connected to an Armen AP 100 (Chromtech, Boronia, VIC, Australia) plunger pump. The two-phase solvent system used consisted of $n$-hexane/acetone/water in a ratio of 5:9:1 $(v / v / v)$. It was equilibrated under stirring at $22{ }^{\circ} \mathrm{C}$ for at least $1 \mathrm{~h}$. Small-scale fractionations as part of the method development were done with a $200-\mathrm{mL}$ rotor in ascending mode (i.e., lower phase is stationary phase) at $22{ }^{\circ} \mathrm{C}$, a rotation speed of $1,000 \mathrm{rpm}$, and a flow rate of $10 \mathrm{~mL} / \mathrm{min}$. The volume of displaced stationary phase was approximately $83 \mathrm{~mL}$. Eighty-five milligrams dried extract was dissolved in a mixture of upper and lower phase, $4 \mathrm{~mL}$ of each phase. The fractionation process was monitored using a Jasco UV-2075 UV detector equipped with a 1-mm preparative cell at a wavelength of $330 \mathrm{~nm}$ (absorbance is expressed as relative response to the highest peak).

For the actual fractionation of the licorice root extract, a $1,000-\mathrm{mL}$ rotor was used $\left(22{ }^{\circ} \mathrm{C}\right.$; rotation speed $1,100 \mathrm{rpm}$; flow rate $25 \mathrm{~mL} / \mathrm{min}$ ). The volume of displaced stationary phase in the $1,000 \mathrm{~mL}$ rotor was approximately $625 \mathrm{~mL}$. Seven hundred fifty milligrams dried extract was dissolved in $28 \mathrm{~mL}$ of a mixture of upper and lower phase (1:1). Seven subsequent runs were performed that resulted in 51 fractions per run; the fraction size was $50 \mathrm{~mL}$. Based on the CPC UV profile, corresponding fractions were combined and evaporated in combination with lyophilization in order to remove solvents. The combined fractions were resolubilized in absolute ethanol $(\mathrm{EtOH})$ and stored at $-20^{\circ} \mathrm{C}$. All samples were thawed and centrifuged before analysis. Fractions collected were analyzed by ultra-high performance liquid chromatography (UHPLC)mass spectrometry at a concentration of $1 \mathrm{mg} / \mathrm{mL}$.

Reversed-phase UHPLC Samples were analyzed using an Accela UHPLC system (Thermo Scientific, San Jose, CA, USA) equipped with pump, autosampler, and PDA detector. Samples $(1 \mu \mathrm{L})$ were injected onto an Acquity UPLC BEH C18 column $(2.1 \times 150 \mathrm{~mm}, 1.7 \mu \mathrm{m}$ particle size $)$ with an Acquity UPLC BEH C18 Vanguard pre-column $(2.1 \times$ $5 \mathrm{~mm}, 1.7 \mu \mathrm{m}$ particle size; Waters, Milford, MA, USA). Eluents were water-acidified with $0.1 \%(v / v)$ acetic acid (eluent A) and acetonitrile-acidified with $0.1 \%(v / v)$ acetic 
acid (eluent B). The flow rate was $300 \mu \mathrm{L} / \mathrm{min}$, and the PDA detector was set to measure at a range of $205-400 \mathrm{~nm}$. The following elution profile was used at $0-18 \mathrm{~min}$, linear gradient from $10-100 \%(v / v) \mathrm{B} ; 18-22 \mathrm{~min}$, isocratic on $100 \% \mathrm{~B} ; 22-23 \mathrm{~min}$, linear gradient from $100-10 \% \mathrm{~B}$; and $23-25 \mathrm{~min}$, isocratic on $10 \% \mathrm{~B}$.

Electrospray ionization mass spectrometry (ESI-MS) Mass spectrometric data were obtained by analyzing samples on an ion trap LTQ-XL (Thermo Scientific) equipped with an ESI-MS probe coupled to the reversed-phase UHPLC. Helium was used as sheath gas and nitrogen as auxiliary gas. Data were collected over an $\mathrm{m} / \mathrm{z}$-range of $150-1,500$. Data-dependent tandem mass spectrometry $\left(\mathrm{MS}^{\mathrm{n}}\right)$ analysis was performed with a normalized collision energy of $35 \%$. The $\mathrm{MS}^{\mathrm{n}}$ fragmentation was always performed on the most intense daughter ion in the $\mathrm{MS}^{\mathrm{n}-1}$ spectrum. Most settings were optimized via automatic tuning using "Tune Plus" (Xcalibur 2.0.7, Thermo Scientific). To this end, the system was tuned with glabridin in both positive ionization and negative ionization mode. In both modes, the ion transfer tube temperature was $350{ }^{\circ} \mathrm{C}$ and the source voltage, $4.8 \mathrm{kV}$. Data acquisition and reprocessing were done with Xcalibur 2.0.7. Mass spectral data interpretation and peak determination were performed with Mass Frontier 5.0 (Highchem, Bratislava, Slovakia).

Determination of estrogenic activity The protocols for the yeast estrogen bioassays were adopted from Bovee et al. [20] with slight modifications. The genetically modified yeast strains have a strong constitutive expression vector stably integrated in the genome to express either the human estrogen receptor $\alpha(E R \alpha)$ or the human estrogen receptor $\beta$ (ER $\beta)$. The yeast genome also contains a reporter construct. This reporter construct contains an inducible yeast-enhanced green fluorescent protein (yEGFP) regulated by the activation of a minimal promoter with estrogenresponsive elements. Cultures of the yeast estrogen biosensor with either $\mathrm{ER} \alpha$ or $\mathrm{ER} \beta$ were grown overnight at $30^{\circ} \mathrm{C}$ with shaking at $200 \mathrm{rpm}$. At the late log phase, the cultures of both estrogen receptors were diluted in the selective minimal medium supplemented with either leucine $(\mathrm{ER} \alpha)$ or histidine $(\mathrm{ER} \beta)$ to an optical density (OD) value $(630 \mathrm{~nm})$ of $0.05 \pm$ $0.01(\mathrm{ER} \alpha)$ and $0.15 \pm 0.05$ (ER $\beta$ ). For exposure, $200-\mu \mathrm{L}$ aliquots of these diluted yeast cultures were combined with $2 \mu \mathrm{L}$ of test compound or extract (in various concentrations) in a 96-well plate to test the agonistic properties of these compounds. DMSO (blank) and control samples containing $17 \beta$-estradiol $\left(E_{2}\right)$ or genistein dissolved in DMSO were included in each experiment. Dilution series of each sample were prepared in DMSO, and the final concentration of DMSO in the assay did not exceed 1\% $(v / v)$. Each sample concentration was assayed in triplicate. Exposure was performed for 24 or $6 \mathrm{~h}$ for the ER $\alpha$ or ER $\beta$ assay, respectively, at $30{ }^{\circ} \mathrm{C}$ and orbital shaking at $200 \mathrm{rpm}$.

Fluorescence and OD were measured at 0 and $24 \mathrm{~h}$ for the ER $\alpha$ and 0 and $6-8 \mathrm{~h}$ for the ER $\beta$ in a Tecan Infinite F500 (Männedorf, Switzerland), using an excitation filter of $485 \mathrm{~nm}$ (bandwidth, $20 \mathrm{~nm}$ ) and an emission filter of $535 \mathrm{~nm}$ (bandwidth, $35 \mathrm{~nm}$ ). The fluorescence signals of the samples were corrected with the signal obtained with the diluted yeast suspension at $\mathrm{t} 0 \mathrm{~h}$ (background signal). In order to check the viability of the yeast in each well, the absorbance was measured at $630 \mathrm{~nm}$. Each fraction was tested in a concentration series ranging from $0.1-100 \mu \mathrm{g} / \mathrm{mL}$. $\mathrm{EC}_{50}$ calculations were performed in Sigma Plot (8.02, SPSS Inc.). In a number of cases, a concentration of $10 \mu \mathrm{g} / \mathrm{mL}$ for the $\mathrm{ER} \alpha$ and $3 \mu \mathrm{g} / \mathrm{mL}$ for the $\mathrm{ER} \beta$ resulted in decreased yeast growth during incubation of more than $50 \%$ during incubation due to cytotoxicity. This cytotoxicity could be due to the anti-microbial properties of licorice root constituents as reported before [21, 22].

A dilution series of estradiol and genistein were used as reference controls in this bioassay. The $\mathrm{EC}_{50}$ values in the $\mathrm{ER} \alpha$ bioassay were $0.86 \mathrm{nM}$ and $1.73 \mu \mathrm{M}$ for estradiol and genistein, respectively, and 0.12 and $9.1 \mathrm{nM}$ in the $\mathrm{ER} \beta$ bioassay, respectively. All $\mathrm{EC}_{50}$ values were in line with those reported previously [20].

For the determination of ER antagonism, the yeast cells were exposed to the $\mathrm{EC}_{70}(\mathrm{ER} \alpha)$ or the $\mathrm{EC}_{90}(\mathrm{ER} \beta)$ of estradiol in combination with different dilutions of a test compound or fraction (measured in triplicates). As a positive control, the yeast cells were exposed to the $\mathrm{EC}_{70}$ of estradiol in combination with the known $\mathrm{ER} \alpha$ antagonist RU 58688 [23]. For ER $\beta$ antagonism, the yeast cells were exposed to the $\mathrm{EC}_{90}$ of estradiol in combination with $R, R$ THC, a known antagonist on the ER $\beta$ [24].

In addition to the yeasts expressing the yEGFP reporter gene in combination with either ER $\alpha$ or $E R \beta$, a third yeast strain was used that only contained the reporter gene but not the vector with the ER. This yeast strain was used as a negative control.

\section{Results and discussion}

Estrogenic activity of CPC fractions for $\mathrm{ER} \alpha$ and $\mathrm{ER} \beta$

CPC fractionation of the licorice root extract resulted in 51 fractions (Fig. 1). After the $51^{\text {st }}$ fraction, no UV response was observed anymore. Fractions F1 to 5, F6 to 21, and F22 to 51 comprised $\sim 25, \sim 40$, and $\sim 35 \%$ DW of the total extraction yield, respectively (Electronic Supplementary Material Table S1). Most fractions showed some estrogenicity on both ERs, indicating the presence of phytoestrogens (Table 1). 
Fig. 1 UV profile of the licorice root extract fractionation by CPC. Estrogenically active fractions are indicated

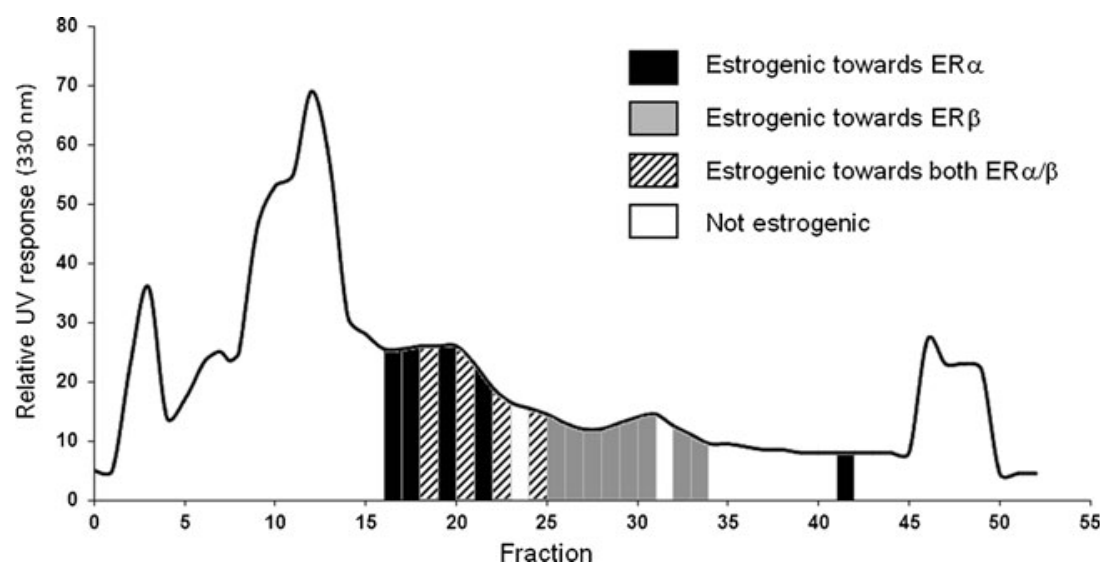

Table 1 Estrogenic response of CPC fractions from the EA extract of licorice roots

\begin{tabular}{|c|c|c|c|c|c|c|c|c|c|}
\hline & $3 \mu \mathrm{g} / \mathrm{mL}$ & $10 \mu \mathrm{g} / \mathrm{mL}$ & $0.3 \mu \mathrm{g} / \mathrm{mL}$ & $1.0 \mu \mathrm{g} / \mathrm{mL}$ & & $3 \mu \mathrm{g} / \mathrm{mL}$ & $10 \mu \mathrm{g} / \mathrm{mL}$ & $0.3 \mu \mathrm{g} / \mathrm{mL}$ & $1.0 \mu \mathrm{g} / \mathrm{mL}$ \\
\hline $\mathrm{Fr}$ & $\mathrm{ER} \alpha$ & $\mathrm{ER} \alpha$ & $E R \beta$ & $E R \beta$ & $\mathrm{Fr}$ & $\mathrm{ER} \alpha$ & $\mathrm{ER} \alpha$ & $E R \beta$ & $E R \beta$ \\
\hline $\mathrm{E}_{2}$ & 100 & & 100 & & $\mathrm{~F} 26^{\mathrm{a}}$ & $38.7( \pm 1.9)$ & $93.7( \pm 6.1)$ & $95.5( \pm 3.4)$ & $151.3( \pm 15.1)$ \\
\hline $\mathrm{F} 1$ & ND & ND & $0.0( \pm 2.0)$ & $0.0( \pm 2.0)$ & $\mathrm{F} 27^{\mathrm{a}}$ & $36.6( \pm 0.3)$ & $90.8( \pm 2.1)$ & $74.6( \pm 5.9)$ & $176.5( \pm 11.8)$ \\
\hline $\mathrm{F} 2$ & ND & $1.1( \pm 1.2)$ & $0.0( \pm 6.5)$ & $0.0( \pm 4.9)$ & $\mathrm{F} 28^{\mathrm{a}}$ & $19.4( \pm 1.9)$ & $48.2( \pm 2.7)$ & $68.7( \pm 4.0)$ & $104.4( \pm 8.3)$ \\
\hline F3 & ND & $4.9( \pm 0.7)$ & $1.6( \pm 1.5)$ & $0.0( \pm 4.5)$ & $\mathrm{F} 29^{\mathrm{a}}$ & $19.9( \pm 1.3)$ & $23.0( \pm 3.9)$ & $57.2( \pm 12.5)$ & $93.5( \pm 0.6)$ \\
\hline F4 & ND & $7.8( \pm 0.8)$ & $13.4( \pm 5.0)$ & $22.4( \pm 7.7)$ & $\mathrm{F} 30^{\mathrm{a}}$ & $23.8( \pm 2.7)$ & $22.4( \pm 1.8)$ & $57.3( \pm 1.1)$ & $48.2( \pm 2.8)$ \\
\hline F5 & $3.0( \pm 2.3)$ & $7.8( \pm 0.3)$ & $12.0( \pm 5.1)$ & $19.5( \pm 2.2)$ & F31 & $25.0( \pm 1.5)$ & $34.2( \pm 1.9)$ & $25.8( \pm 8.5)$ & $40.5( \pm 17.8)$ \\
\hline F6 & ND & ND & ND & ND & $\mathrm{F} 32^{\mathrm{a}}$ & $26.8( \pm 2.3)$ & $34.5( \pm 2.0)$ & $57.4( \pm 4.7)$ & $47.4( \pm 10.7)$ \\
\hline F7 & $17.1( \pm 3.0)$ & $21.0( \pm 2.7)$ & $21.4( \pm 5.6)$ & $12.2( \pm 2.2)^{\mathrm{b}}$ & $\mathrm{F} 33^{\mathrm{a}}$ & $32.0( \pm 1.4)$ & $38.0( \pm 0.4)$ & $50.2( \pm 9.5)$ & $36.0( \pm 3.2)$ \\
\hline F8 & $10.5( \pm 2.2)$ & $21.8( \pm 6.3)$ & $17.2( \pm 2.3)$ & $58.3( \pm 3.4)$ & F34 & $29.6( \pm 5.3)$ & $44.9( \pm 1.3)$ & $27.7( \pm 8.8)$ & $46.1( \pm 5.2)$ \\
\hline F9 & $13.3( \pm 1.5)$ & $7.1( \pm 6.4)$ & $37.8( \pm 10.0)$ & $49.1( \pm 21.5)$ & F35 & $30.8( \pm 3.1)$ & $45.5( \pm 4.2)$ & $43.6( \pm 7.6)$ & $37.5( \pm 21.0)$ \\
\hline F10 & $9.7( \pm 3.3)$ & $9.3( \pm 2.0)$ & $23.0( \pm 9.5)$ & $57.3( \pm 12.9)$ & F36 & $42.8( \pm 2.3)$ & $42.9( \pm 6.5)$ & $19.9( \pm 2.3)$ & $45.3( \pm 2.5)$ \\
\hline F11 & $\mathrm{ND}$ & ND & $46.3( \pm 12.0)$ & $\mathrm{ND}^{\mathrm{b}}$ & F37 & $13.6( \pm 1.6)$ & $25.3( \pm 2.5)$ & $24.8( \pm 2.6)$ & $35.1( \pm 9.9)$ \\
\hline $\mathrm{F} 12$ & $15.6( \pm 2.9)$ & $15.7( \pm 3.2)^{\mathrm{b}}$ & $30.7( \pm 0.1)$ & $77.2( \pm 7.3)$ & F38 & $14.8( \pm 1.7)$ & $28.8( \pm 0.5)$ & $14.2( \pm 6.8)$ & $30.8( \pm 15.4)$ \\
\hline $\mathrm{F} 13$ & ND & ND & $40.3( \pm 5.0)$ & $2.4( \pm 4.9)^{\mathrm{b}}$ & F39 & $19.8( \pm 1.6)$ & $32.4( \pm 2.6)$ & $21.1( \pm 4.4)$ & $45.6( \pm 14.7)$ \\
\hline F14 & $4.8( \pm 4.7)$ & ND & $42.7( \pm 6.6)$ & $73.3( \pm 4.1)$ & F40 & $25.6( \pm 4.3)$ & $33.9( \pm 2.3)$ & $26.5( \pm 5.5)$ & $35.4( \pm 17.4)$ \\
\hline F15 & $\mathrm{ND}$ & $\mathrm{ND}$ & $28.4( \pm 7.1)$ & $77.7( \pm 1.8)$ & $\mathrm{F} 41^{\mathrm{a}}$ & $159.9( \pm 9.5)$ & $186.9( \pm 15.0)$ & $28.3( \pm 4.9)$ & $34.9( \pm 13.5)$ \\
\hline $\mathrm{F} 16^{\mathrm{a}}$ & $74.8( \pm 4.0)$ & $20.4( \pm 28.9)^{\mathrm{b}}$ & $40.7( \pm 1.0)$ & $62.6( \pm 2.1)$ & $\mathrm{F} 42$ & $21.6( \pm 6.0)$ & $26.2( \pm 2.2)$ & $19.8( \pm 11.0)$ & $53.8( \pm 25.5)$ \\
\hline $\mathrm{F} 17^{\mathrm{a}}$ & $109.1( \pm 2.3)$ & $49.3( \pm 4.4)^{\mathrm{b}}$ & $36.7( \pm 9.5)$ & $88.8( \pm 8.2)$ & F43 & $26.5( \pm 1.8)$ & $24.7( \pm 4.3)$ & $25.4( \pm 1.2)$ & $38.9( \pm 20.0)$ \\
\hline $\mathrm{F} 18^{\mathrm{a}}$ & $105.3( \pm 6.2)$ & $104.6( \pm 10.5)^{\mathrm{b}}$ & $57.1( \pm 9.4)$ & $98.8( \pm 15.1)$ & F44 & $18.9( \pm 1.9)$ & $24.6( \pm 1.5)$ & $22.7( \pm 7.3)$ & $33.8( \pm 12.2)$ \\
\hline $\mathrm{F} 19^{\mathrm{a}}$ & $89.1( \pm 4.2)$ & $131.2( \pm 16.2)$ & $48.3( \pm 4.6)$ & $123.8( \pm 17.1)$ & F45 & $20.9( \pm 1.5)$ & $21.0( \pm 4.3)$ & $19.6( \pm 3.4)$ & $66.3( \pm 15.1)$ \\
\hline $\mathrm{F} 20^{\mathrm{a}}$ & $60.2( \pm 3.1)$ & $140.5( \pm 10.7)$ & $60.5( \pm 14.5)$ & $116.7( \pm 14.3)$ & F46 & $16.9( \pm 1.2)$ & $20.5( \pm 3.2)$ & $18.0( \pm 11.6)$ & $73.8( \pm 7.3)$ \\
\hline $\mathrm{F} 21^{\mathrm{a}}$ & $71.9( \pm 8.4)$ & $125.3( \pm 1.2)$ & $45.2( \pm 3.8)$ & $145.9( \pm 25.2)$ & F47 & $21.2( \pm 2.9)$ & $23.3( \pm 4.2)$ & $31.0( \pm 5.1)$ & $79.4( \pm 6.1)$ \\
\hline $\mathrm{F} 22^{\mathrm{a}}$ & $101.4( \pm 11.6)$ & $134.1( \pm 2.7)$ & $87.0( \pm 10.3)$ & $144.4( \pm 10.7)$ & $\mathrm{F} 48$ & $23.2( \pm 4.6)$ & $21.7( \pm 2.4)$ & $26.8( \pm 2.5)$ & $49.1( \pm 17.8)$ \\
\hline F23 & $16.0( \pm 0.9)$ & $83.0( \pm 9.9)$ & $26.3( \pm 8.7)$ & $84.8( \pm 7.0)$ & F49 & $26.4( \pm 0.6)$ & $26.7( \pm 0.3)$ & $16.5( \pm 3.0)$ & $82.9( \pm 4.9)$ \\
\hline $\mathrm{F} 24^{\mathrm{a}}$ & $79.6( \pm 1.6)$ & $156.3( \pm 14.4)$ & $103.1( \pm 2.3)$ & $159.3( \pm 23.1)$ & F50 & $18.8( \pm 2.7)$ & $16.7( \pm 3.2)$ & $7.3( \pm 9.3)$ & $41.3( \pm 3.1)$ \\
\hline $\mathrm{F} 25^{\mathrm{a}}$ & $44.2( \pm 5.7)$ & $108.6( \pm 3.9)$ & $97.9( \pm 10.6)$ & $172.8( \pm 20.7)$ & F51 & $22.0( \pm 3.2)$ & $15.6( \pm 2.5)$ & $18.8( \pm 2.7)$ & $40.5( \pm 18.3)$ \\
\hline
\end{tabular}

The estrogenicity toward the ER $\alpha$ and the ER $\beta$ was measured at two concentrations. The activity was standardized to the maximum induced response of $2 \mu \mathrm{M}$ estradiol (100\%). Values are the mean $\pm \mathrm{SD}(n=3)$. Estrogenic fractions are marked

$\mathrm{Fr}$ fraction, $N D$ not detected (estrogenicity values were zero or slightly negative)

${ }^{\text {a }}$ Estrogenically active

${ }^{\mathrm{b}}$ Inhibited yeast growth due to cytotoxicity 
A compound is considered a phytoestrogen when it activates the $\mathrm{ER}$ at concentrations $\leq 10^{4}$ times than that of estradiol $\left(\mathrm{E}_{2}\right)$ [25]. The $\mathrm{EC}_{50}$ value of $\mathrm{E}_{2}$ towards the $\mathrm{ER} \alpha$ in the yeast assay was determined to be $1.0-1.6 \times 10^{-9} \mathrm{M}$, which corresponds to $2.7-4.4 \times 10^{-4} \mu \mathrm{g} / \mathrm{mL}$. Therefore, only $\mathrm{CPC}$ fractions giving a response above the $\mathrm{EC}_{50}$ at a dilution below $3 \mu \mathrm{g} / \mathrm{mL}$ were indicated as active towards $\mathrm{ER} \alpha$ in Fig. 1. The application of this threshold value for the ER $\alpha$ resulted in nine active fractions out of 51 (see Table 1).

The $\mathrm{EC}_{50}$ value of $\mathrm{E}_{2}$ towards the $\mathrm{ER} \beta$ ranged from $1.1 \times 10^{-10}$ to $2.1 \times 10^{-10} \mathrm{M}$, corresponding to an $\mathrm{EC}_{50}$ of $3.2-5.9 \times 10^{-5} \mu \mathrm{g} / \mathrm{mL}$. Therefore, only CPC fractions giving a response above the $\mathrm{EC}_{50}$ at a dilution below $0.3 \mu \mathrm{g} / \mathrm{mL}$ were indicated as active towards ER $\beta$ in Fig. 1. The
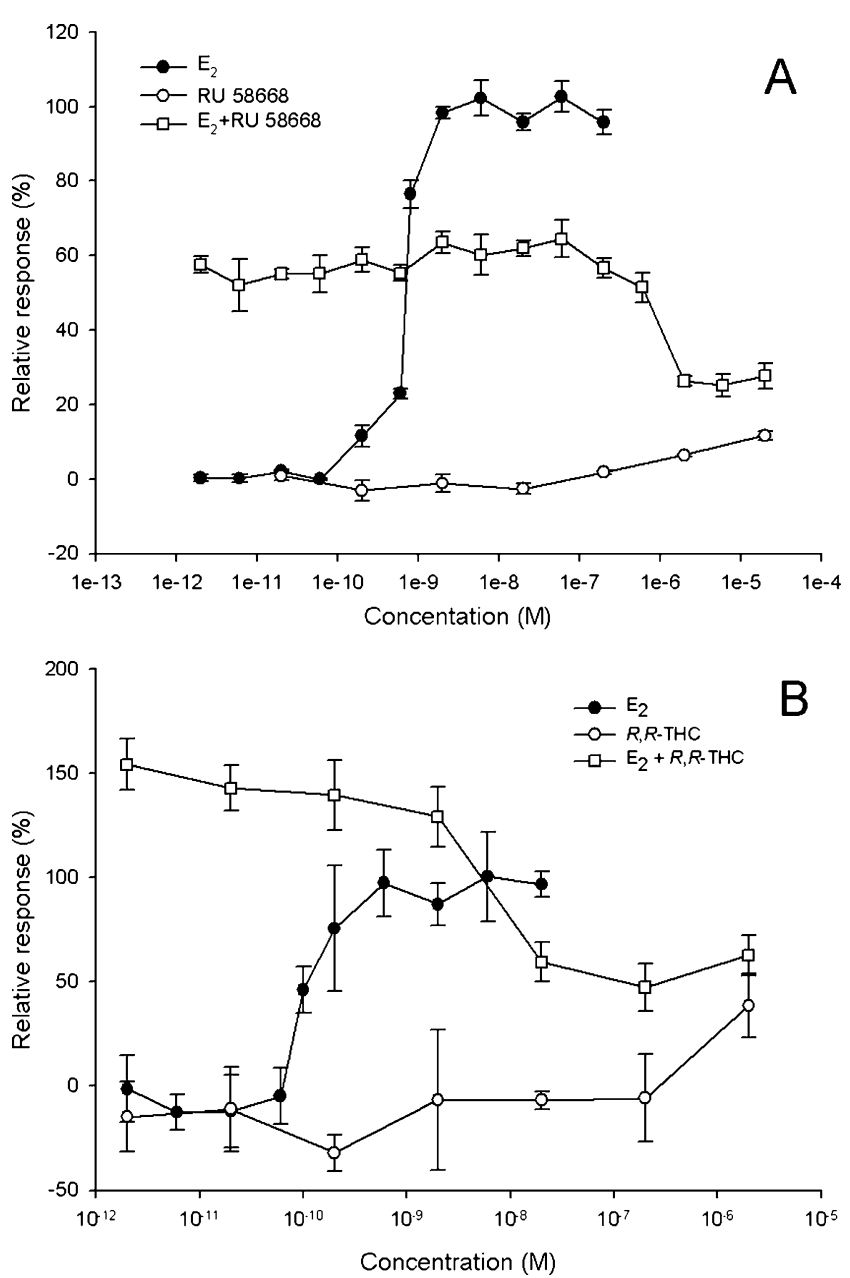

Fig. 2 Transcription activation by $\operatorname{ER} \alpha(\mathbf{A})$ and $\operatorname{ER} \beta(\mathbf{B})$ in response to $\mathrm{E}_{2}$ and subtype-selective antagonists RU58668 (ER $\left.\alpha\right)$ and $R, R$ THC $(\mathrm{ER} \beta)$. The antagonistic activity of both receptor-specific antagonists were assayed in the presence of the $\mathrm{EC}_{70}(0.8 \mathrm{nM})$ and $\mathrm{EC}_{90}(0.2 \mathrm{nM}) \mathrm{E}_{2}$ for $\mathrm{ER} \alpha$ and $\mathrm{ER} \beta$, respectively. Both graphs were normalized to $\mathrm{E}_{2}$. The response of $R, R-\mathrm{THC}$ on $\mathrm{ER} \beta$ for every concentration was lower than the minimum response of $E_{2}$. This was corrected by normalizing the lowest concentration of $R, R$-THC to $0 \%$. Values are the mean \pm SD $(n=3)$ application of this threshold value for the ER $\beta$ resulted in 12 active fractions out of 51 (Table 1).

The screening for estrogenicity of the $\mathrm{CPC}$ fractions on both receptor subtypes showed that the estrogenic response of several fractions substantially exceeded the maximum response of $\mathrm{E}_{2}$ (Table 1). This phenomenon has been referred to as superinduction [26]. In our study, this superinduction was observed with both receptors and appeared more pronounced for ER $\beta$. The mechanism that leads to superinduction is not well understood but sometimes occurs with colored extracts. Such colored extracts can disturb the fluorescent measurement, as, due to a decrease of the $\mathrm{pH}$ during the exposure period, the color can change as well.

To determine whether fractions gave an increased fluorescent response as a result of acidification (change of $\mathrm{pH} 5.0$ to $\mathrm{pH} 2.9$ ) of the culture medium due to yeast growth, six representative fractions (F4, F13, F22, F27, F30, and F44), with no, moderate, or high estrogenic activity, were measured at different $\mathrm{pH}$ values in the absence of yeast. No altered fluorescent signals were observed compared with the blank, showing that the observed superinduction was not related to altered fluorescent signals due to a drop in $\mathrm{pH}$.

In a next series of experiments, two subtype-selective antagonists were used to determine whether the observed estrogenic activities, including the superinduction, were ERmediated. First, RU 58668 (ER $\alpha$-selective) [27] and $R, R$-THC (ER $\beta$-selective) [24] were tested in the yeast estrogen bioassays to confirm their antagonistic properties. Coincubation of $\mathrm{E}_{2}$ and RU 58668 showed that $6 \times 10^{-6} \mathrm{M}$ RU 58668 was able to decrease the $\mathrm{E}_{2}$-induced response of $\mathrm{ER} \alpha$ by $\sim 60 \%$ (Fig. 2A). RU 58668 itself showed a weak agonistic activity of $\sim 12 \%$ in concentrations above $1 \times 10^{-5}$

Table 2 Inhibition of estrogenic response of representative CPC fractions by addition of a subtype-specific antagonist

\begin{tabular}{lllll}
\hline & $\begin{array}{l}\text { Estrogenic } \\
\text { activity ER } \alpha\end{array}$ & $\begin{array}{l}\text { Inhibition by } \\
\text { RU 58668 }\end{array}$ & $\begin{array}{l}\text { Estrogenic } \\
\text { activity ER } \beta\end{array}$ & $\begin{array}{l}\text { Inhibition } \\
\text { by } R, R \text {-THC }\end{array}$ \\
\hline $\mathrm{E}_{2}$ & 100 & $60 \%$ & 100 & $55 \%$ \\
F4 & ND & - & $13.4( \pm 5.0)$ & $70 \%$ \\
F13 & ND & - & $40.3( \pm 5.0)$ & $37 \%$ \\
F22 & $101.4( \pm 11.6)$ & $52 \%$ & $87.0( \pm 10.3)$ & $34 \%$ \\
F27 & $36.6( \pm 0.3)$ & $21 \%$ & $74.6( \pm 5.9)$ & $61 \%$ \\
F30 & $23.8( \pm 2.7)$ & $21 \%$ & $57.3( \pm 1.1)$ & $48 \%$ \\
F44 & $18.9( \pm 1.9)$ & $30 \%$ & $22.7( \pm 7.3)$ & $70 \%$ \\
\hline
\end{tabular}

Inhibition of the estrogenic response of six representative $\mathrm{CPC}$ fractions were determined by co-incubation at $1 \mu \mathrm{g} / \mathrm{mL}$ with $6 \times$ $10^{-6} \mathrm{M}$ RU 58668 for the ER $\alpha$ and $1 \mu \mathrm{g} / \mathrm{mL}$ with $2 \times 10^{-8} \mathrm{M} R, R$ $\mathrm{THC}$ for the ER $\beta$. Values are the mean $\pm \mathrm{SD}(n=3)$

$N D$ not detected 
Fig. 3 Stabilizing effect of E2, genistein, and several fractions obtained from the licorice root extract on the relative activity measured after 6 and $24 \mathrm{~h}$ in the ER $\beta$ assay. $E_{2}, 2 \times 10^{-10} \mathrm{M}$ estradiol; Gen, $2 \times 10^{-7} \mathrm{M}$ genistein; $F 4$ to $F 44$, licorice root fractions obtained by $\mathrm{CPC}$ measured at $0.3 \mu \mathrm{g} / \mathrm{mL}$. Asterisk, negative response

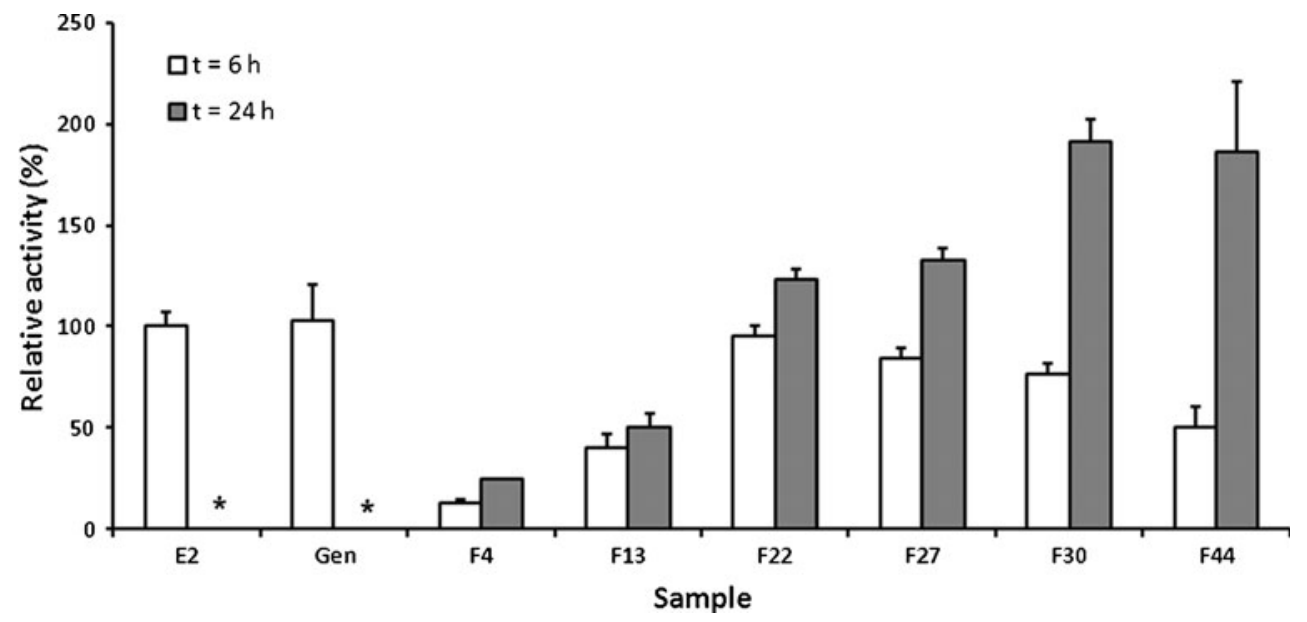

M. RU 58668 is known as a pure ER $\alpha$ antagonist, but its weak agonistic activity in the yeast estrogen bioassay with $\mathrm{ER} \alpha$ is not expected, as several other $11 \beta$-analogues of $\mathrm{E}_{2}$ were shown to be selective estrogen receptor modulators (SERM) with both agonistic and antagonistic activity on the $\mathrm{ER} \alpha$ in the same yeast estrogen bioassay [23].

Co-incubation of $\mathrm{E}_{2}$ and $R, R$-THC showed that $2 \times 10^{-7}$ $\mathrm{M} R, R$-THC was able to decrease the $\mathrm{E}_{2}$-induced response of ER $\beta$ by $\sim 55 \%$ (Fig. $2 \mathrm{~B}$ ). Meyers and co-workers reported an inhibition of $\sim 100 \%$ at similar concentrations while using mammalian cell-based assays [24].
To determine whether the observed estrogenic responses of the fractions were ER-mediated, selected fractions were co-incubated with the subtype-selective antagonists. Besides, the fractions were tested in the yeast strain that expresses no estrogen receptor and only contains the reporter construct. In all estrogen-active fractions, the responses were inhibited by either RU 58668 or $R, R$-THC, and the fluorescence response was reduced by up to $70 \%$. This confirms that the estrogenic responses caused by the fractions on both receptors were ER-mediated (Table 2). Also, the controls with the yeast strain expressing no ER confirmed that the observed

Table 3 Fractions generated by CPC fractionation and the presence of the main flavonoids in each fraction determined by ultra-high performance LC-MS

\begin{tabular}{|c|c|c|c|c|c|c|c|c|c|c|c|c|c|c|c|}
\hline Fraction & 6 & 7 & 8 & 9 & 10 & 11 & 12 & 13 & 14 & 15 & 16 & 17 & 18 & 19 & 20 \\
\hline Yield (mg) & 110 & 141 & 97 & 136 & 108 & 126 & 211 & 345 & 254 & 156 & 66 & 176 & 157 & 115 & 37 \\
\hline Number of peaks & 20 & 6 & 12 & 25 & 22 & 18 & 7 & 4 & 6 & 6 & 15 & 14 & 17 & 30 & 42 \\
\hline \multicolumn{16}{|l|}{ Of which are } \\
\hline Non-prenylated & 3 & 1 & 2 & 4 & 2 & 1 & 0 & 0 & 0 & 0 & 0 & 1 & 2 & 4 & 9 \\
\hline Prenylated & 17 & 5 & 10 & 21 & 20 & 17 & 7 & 4 & 6 & 6 & 15 & 13 & 15 & 26 & 33 \\
\hline Single-prenylated & 13 & 3 & 7 & 9 & 6 & 8 & 4 & 1 & 2 & 3 & 11 & 11 & 13 & 18 & 22 \\
\hline Chain & 7 & 2 & 4 & 6 & 4 & 5 & 2 & 0 & 1 & 2 & 7 & 5 & 9 & 13 & 21 \\
\hline Pyran & 6 & 1 & 3 & 3 & 2 & 3 & 2 & 1 & 1 & 1 & 4 & 6 & 4 & 5 & 1 \\
\hline Double-prenylated & 4 & 2 & 3 & 12 & 14 & 9 & 3 & 3 & 4 & 3 & 4 & 2 & 2 & 8 & 11 \\
\hline \multicolumn{16}{|l|}{ Characterization } \\
\hline Glabrene & & & & & & & & & & & ++ & ++ & ++ & ++ & + \\
\hline Glabrone & & & & + & + & ++ & + & & & & & & & & \\
\hline Glabridin & & & & & & + & + & ++ & ++ & + & + & + & & & \\
\hline Glabrol & & & & & & + & ++ & ++ & + & + & & & & & \\
\hline $3^{\prime}-\mathrm{OH}-4^{\prime} \mathrm{OMe}-\mathrm{G}^{\mathrm{a}}$ & & & + & + & ++ & ++ & & & & & & & & & \\
\hline $4^{\prime}-\mathrm{OMe}-\mathrm{G}^{\mathrm{b}}$ & + & + & ++ & + & & & & & & & & & & & \\
\hline Hispaglabridin A & + & ++ & ++ & & & & & & & & & & & & \\
\hline Hispaglabridin B & ++ & ++ & + & & & & & & & & & & & & \\
\hline
\end{tabular}

a $4^{\prime}-O$-methyl-glabridin

b 3'-hydroxy-4'-O-methyl-glabridin 
Fig. 4 Main flavonoids identified in CPC fractions 6-21 obtained from the EA extract of licorice root
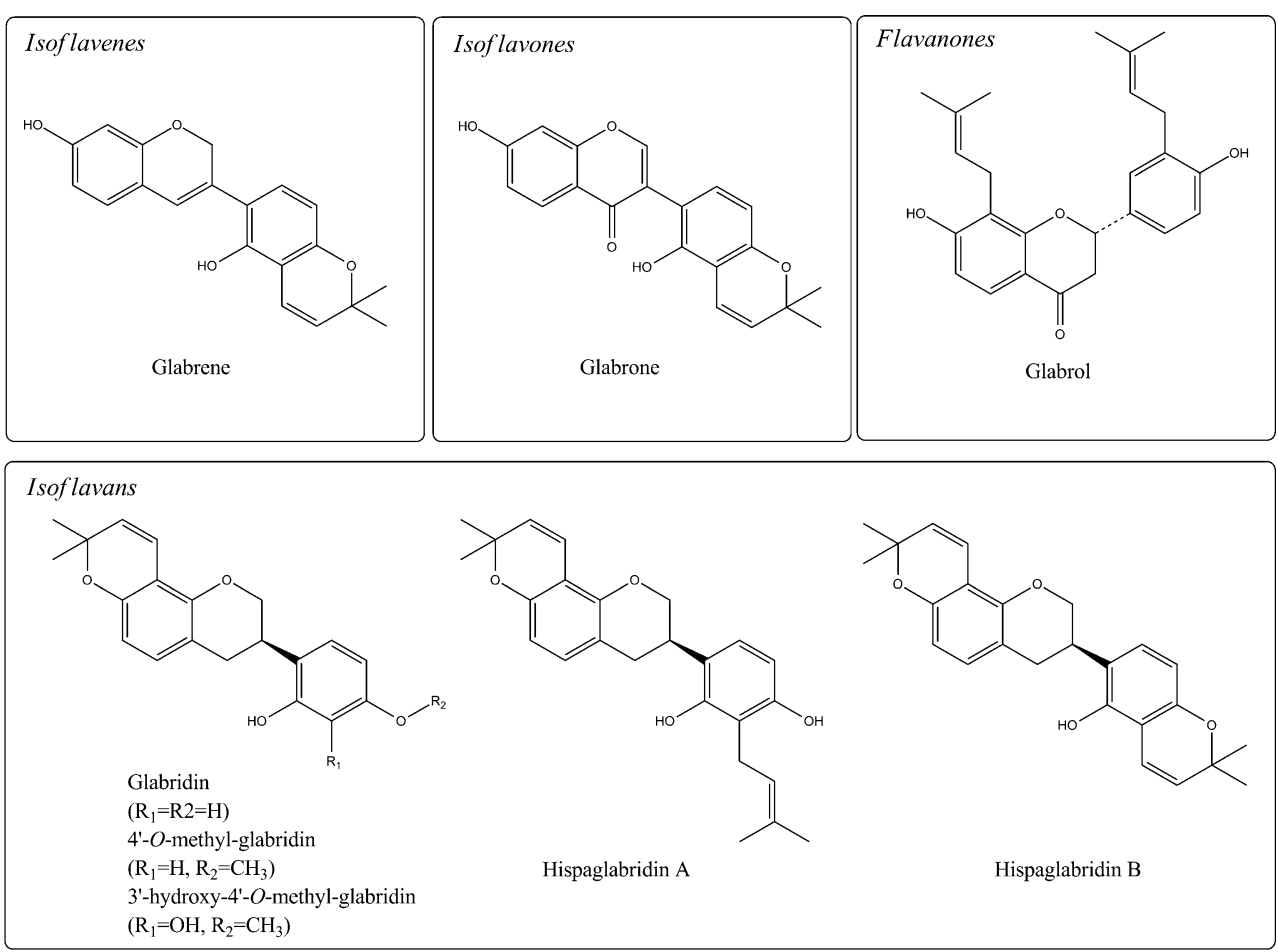

responses were ER-mediated, as no fluorescent signal was observed for any of the fractions or $E_{2}$.

\section{Superinduction by stabilization of ER-mediated response}

The phenomenon of superinduction has been previously observed in several assay types and the superinduction caused by genistein in human U2OS bone cells transfected with the ER $\alpha$ and a luciferase reporter gene was intensively investigated [26]. It was concluded that this superinduction was caused by a post-translational stabilization of the firefly luciferase reporter enzyme by genistein and not by stabilization of the ER $\alpha$. To verify the hypothesis that superinduction in the yeast was caused by the stabilization of the ER and/or the yEGFP, the yeast expressing ER $\beta$ was co-incubated with $\mathrm{E}_{2}$, genistein, or the representative fractions (F4, F13, F22, F27, F30, and F44) mentioned before. The estrogenic responses were measured after 6 and $24 \mathrm{~h}$ (Fig. 3). After $6 \mathrm{~h}$, both $\mathrm{E}_{2}$ and genistein showed the maximum estrogenic response, but, as expected, the estrogenic response of $\mathrm{E}_{2}$ completely disappeared after $24 \mathrm{~h}$. Also, the response of genistein completely disappeared, whereas the estrogenic response of the fractions was similar or even higher compared with their response measured after $6 \mathrm{~h}$. This strongly indicates that the responses, including the superinduction, of the fractions were stabilized. Our results do not allow speculation on whether the ER, the yEGFP, or both proteins were stabilized, but the observed estrogenic responses were without doubt ER-mediated.
LC-MS characterization of licorice fractions

Because the estrogenic responses were ER-mediated, the licorice fractions were subjected to characterization by LCMS. Fractions F6-21 contained the main flavonoids previously annotated in the EA extract of licorice roots (Table 3, Fig. 4) [11]. These flavonoids have been annotated based on UV and $\mathrm{MS}^{\mathrm{n}}$ spectra and, if possible, compared with spectra published in the literature. The estrogenic activity of a number of active fractions (F2022,24-30,32-33,42) could not be traced back to individual components (Electronic Supplementary Material Table S1).

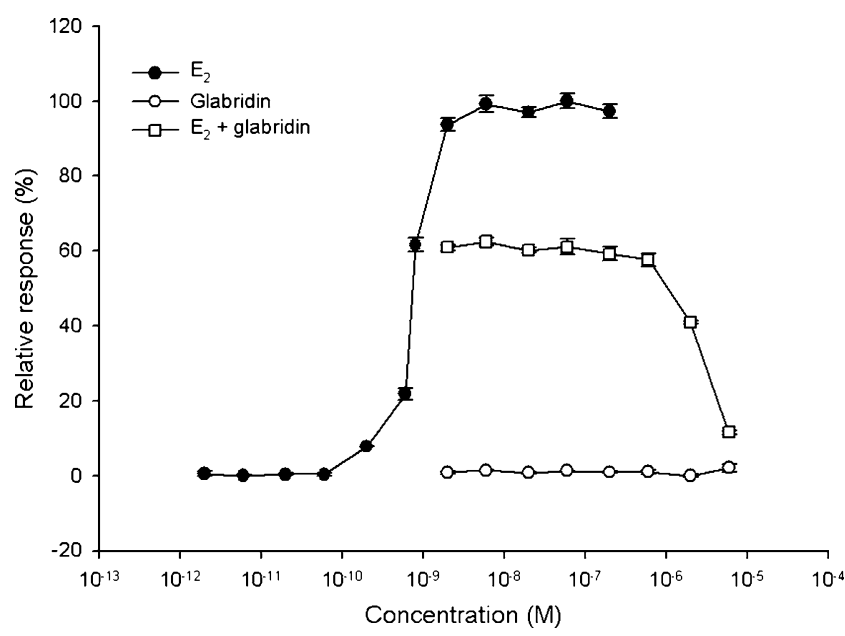

Fig. 5 Antagonistic activity of glabridin on the estrogenic response in the $\mathrm{ER} \alpha$ yeast estrogen bioassay 
Compositional analysis by LC-MS showed that the active fractions were complex mixtures, indicating that further purification of CPC fractions is prerequisite for the identification of the estrogenic compounds. In most cases, it was not possible to assign the identity of the predominant peaks by UV and $\mathrm{MS}^{\mathrm{n}}$. Furthermore, in most fractions, the majority of the compounds were prenylated, which might suggest a correlation between prenylation and superinduction (Table 3, Electronic Supplementary Material Table S1).

Fractions F16-20, rich in glabrene, showed a predominant estrogenic activity on the ER $\alpha$. This is in agreement with the fact that glabrene is considered one of the principle estrogenic components of licorice root. The estrogenic potency of glabrene for both ER subtypes, however, has not yet been established. Our results indicate that the glabrenerich fractions had a particularly high response towards $\mathrm{ER} \alpha$. Whereas phytoestrogens generally have a more pronounced affinity to the ER $\beta$ compared with the ER $\alpha$, the glabrene-rich fractions showed the opposite behavior, similar to that of 8-prenyl naringenin [27].

In addition to glabrene, the estrogenic activity of licorice roots extract has been ascribed to the presence of glabridin and its derivatives. Despite the abundance of glabridin in F11-15, no significant estrogenic response on both ER subtypes was observed. $\mathrm{EC}_{50}$ values of $5 \times 10^{-6} \mathrm{M}$ have been reported for glabridin, using different mammalian proliferation assays [15-17]. Furthermore, several glabridin derivatives were shown to be moderately estrogenic compared with glabridin [14]. In our study, the pure reference standard of glabridin did not exert any estrogenic response in a concentration range of $1 \times 10^{-7}$ to $1 \times 10^{-4} \mathrm{M}$ towards both ER subtypes (data not shown). In concentrations above $1 \times 10^{-4} \mathrm{M}$, glabridin was toxic to the yeast cells. Because glabridin had been shown to interact with the ERs, and because it is known that different ER-based bioassays can generate different output, glabridin as well as the glabrene-rich fraction F18 (due to the lack of a glabrene reference standard) were tested for their antagonistic properties.

Antagonistic activity of glabridin and glabrene

Prenylation of isoflavonoids has been suggested to induce antagonism towards the $\mathrm{ER} \alpha[5,7,8]$. The glabrene-rich fraction F18 did not show antagonistic activity on both ER subtypes (no further data shown) but increased the estrogenic response upon co-exposure with $\mathrm{E}_{2}$, confirming its agonistic character.

The reference standard of glabridin did not have antagonistic properties towards the ER $\beta$ (data not shown) but was shown to be an ER $\alpha$-selective antagonist (Fig. 5). At a concentration of $6 \times 10^{-6} \mathrm{M}$, glabridin was able to inhibit the $\mathrm{E}_{2}$ response by $\sim 80 \%$ without being toxic towards the yeast cells. The agonistic activity of glabridin in the MCF-7 proliferation assay, in in vivo animal models, and the ER $\alpha$-selective antagonistic activity in the yeast estrogen bioassay might imply that glabridin acts as a SERM. The estrogenic activity of glabridin is similar to kievitone and phaseollin, a prenyl-chain substituted isoflavanone and a pyran-ring substituted pterocarpan, respectively. Both kievitone and phaseollin displayed agonistic activity in the MCF-7 proliferation assay and in the human HEK 293 transactivation assay but were antagonistic in the MCF-7 colony-formation assay [28]. The assay-dependent mode of action of glabridin has also been observed with other compounds. For example, both tamoxifen and 4hydroxy-tamoxifen act as SERMs, displaying both estrogenic and anti-estrogenic activities in mammalian breast and endometrial cells, act as agonists in yeast estrogen bioassays [27].

As mentioned before, LC-MS characterization showed that fractions F6-15 were rich in glabridin derivatives. These compounds share prenyl-substitution on the A-ring with a pyran-ring (Table 3, Fig. 4). It will be worthwhile to also test the purified glabridin derivatives for antagonistic activity in the yeast estrogen bioassay.

Acknowledgments This work was financially supported by the Food and Nutrition Delta of the Ministry of Economic Affairs, The Netherlands. We would like to thank Daniel Piscitello, Florian Wiegand, and Miroslav Bolardt (Frutarom Switzerland Ltd., Wädenswil, Switzerland) for their assistance in preparing the licorice extract and RIKILT-Institute of Food Safety for the yeast estrogen bioassays.

Open Access This article is distributed under the terms of the Creative Commons Attribution Noncommercial License which permits any noncommercial use, distribution, and reproduction in any medium, provided the original author(s) and source are credited.

\section{References}

1. Barron D, Ibrahim RK (1996) Isoprenylated flavonoids-a survey. Phytochemistry 43(5):921-982

2. Botta B, Monache GD, Menendez P, Boffi A (2005) Novel prenyltransferase enzymes as a tool for flavonoid prenylation. Trends Pharmacol Sci 26(12):606-608

3. Kitaoka M, Kadokawa H, Sugano M, Ichikawa K, Taki M, Takaishi S, Iijima Y, Tsutsumi S, Boriboon M, Akiyama T (1998) Prenylflavonoids: a new class of non-steroidal phytoestrogen (part 1). Isolation of 8-isopentenylnaringenin and an initial study on its structure-activity relationship. Planta Med 64(6):511-515

4. Pinto B, Bertoli A, Noccioli C, Garritano S, Reali D, Pistelli L (2008) Estradiol-antagonistic activity of phenolic compounds from leguminous plants. Phytother Res 22(3):362-366

5. Ahn EM, Nakamura N, Akao T, Nishihara T, Hattori M (2004) Estrogenic and antiestrogenic activities of the roots of Moghania philippinensis and their constituents. Biol Pharm Bull 27(4):548-553

6. Roelens F, Heldring N, Dhooge W, Bengtsson M, Comhaire F, Gustafsson JÅ, Treuter E, De Keukeleire D (2006) Subtle sidechain modifications of the hop phytoestrogen 8-prenylnaringenin result in distinct agonist/antagonist activity profiles for estrogen receptors $\alpha$ and $\beta$. J Med Chem 49(25):7357-7365 
7. Jiang Q, Payton-Stewart F, Elliott S, Driver J, Rhodes LV, Zhang Q, Zheng S, Bhatnagar D, Boue SM, Collins-Burow BM, Sridhar J, Stevens C, McLachlan JA, Wiese TE, Burow ME, Wang G (2010) Effects of 7-O substitutions on estrogenic and antiestrogenic activities of daidzein analogues in MCF-7 breast cancer cells. J Med Chem 53(16):6153-6163

8. Okamoto Y, Suzuki A, Ueda K, Ito C, Itoigawa M, Furukawa H, Nishihara T, Kojima N (2006) Anti-estrogenic activity of prenylated isoflavones from Millettia pachycarpa: implications for pharmacophores and unique mechanisms. J Health Sci 52 (2): 186-191

9. Boué SM, Cleveland TE, Carter-Wientjes C, Shih BY, Bhatnagar D, McLachlan JM, Burow ME (2009) Phytoalexinenriched functional foods. J Agric Food Chem 57(7):26142622

10. Nomura T, Fukai T (1998) Phenolic constituents of licorice (Glycyrrhiza species). In: Herz W, Kirby GW, Moore RE, Steglich W, Tamm C (eds) Progress in the chemistry of organic natural products, vol 73. Springer, New York, NY, pp 1-140

11. Simons R, Vincken J-P, Bakx EJ, Verbruggen MA, Gruppen H (2009) A rapid screening method for prenylated flavonoids with ultra-high-performance liquid chromatography/electrospray ionisation mass spectrometry in licorice root extracts. Rapid Commun Mass Spectrom 23(19):3083-3093

12. Kohno H, Kouda K, Tokunaga R, Sonoda Y (2007) Detection of estrogenic activity in herbal teas by in vitro reporter assays. Eur Food Res Technol 225(5-6):913-920

13. Zava DT, Blen M, Duwe G (1997) Estrogenic activity of natural and synthetic estrogens in human breast cancer cells in culture. Environ Health Perspect 105(suppl 3):637-645

14. Tamir S, Eizenberg M, Somjen D, Izrael S, Vaya J (2001) Estrogen-like activity of glabrene and other constituents isolated from licorice root. J Steroid Biochem Mol Biol 78(3):291-298

15. Tamir S, Eizenberg M, Somjen D, Stern N, Shelach R, Kaye A, Vaya J (2000) Estrogenic and antiproliferative properties of glabridin from licorice in human breast cancer cells. Cancer Res 60(20):5704-5709

16. Somjen D, Katzburg S, Vaya J, Kaye AM, Hendel D, Posner GH, Tamir S (2004) Estrogenic activity of glabridin and glabrene from licorice roots on human osteoblasts and prepubertal rat skeletal tissues. J Steroid Biochem Mol Biol 91(4-5):241-246

17. Somjen D, Knoll E, Vaya J, Stern N, Tamir S (2004) Estrogen-like activity of licorice root constituents: glabridin and glabrene, in vascular tissues in vitro and in vivo. J Steroid Biochem Mol Biol 91(3):147-155
18. Shanmugam M, Krett NL, Maizels ET, Cutler RE Jr, Peters CA, Smith LM, O'Brien ML, Park-Sarge OK, Rosen ST, HunzickerDunn M (1999) Regulation of protein kinase C $\delta$ by estrogen in the MCF-7 human breast cancer cell line. Mol Cell Endocrinol 148(1-2):109-118

19. Rachner TD, Schoppet M, Niebergall U, Hofbauer LC (2008) 17ßEstradiol inhibits osteoprotegerin production by the estrogen receptor- $\alpha$-positive human breast cancer cell line MCF-7. Biochem Biophys Res Commun 368(3):736-741

20. Bovee TFH, Helsdingen RJR, Rietjens IMCM, Keijer J, Hoogenboom RLAP (2004) Rapid yeast estrogen bioassays stably expressing human estrogen receptors $\alpha$ and $\beta$, and green fluorescent protein: a comparison of different compounds with both receptor types. J Steroid Biochem Mol Biol 91(3):99-109

21. Nassiri Asl M, Hosseinzadeh H (2008) Review of pharmacological effects of Glycyrrhiza sp. and its bioactive compounds. Phytother Res 22(6):709-724

22. Nomura T, Fukai T, Akiyama T (2002) Chemistry of phenolic compounds of licorice (Glycyrrhiza species) and their estrogenic and cytotoxic activities. Pure Appl Chem 74(7):1199-1206

23. Bovee TFH, Thevis M, Hamers ARM, Peijnenburg AACM, Nielen MWF, Schoonen WGEJ (2010) SERMs and SARMs: detection of their activities with yeast based bioassays. J Steroid Biochem Mol Biol 118(1-2):85-92

24. Meyers MJ, Jun S, Carlson KE, Katzenellenbogen BS, Katzenellenbogen JA (1999) Estrogen receptor subtypeselective ligands: asymmetric synthesis and biological evaluation of cis- and trans-5,11-dialkyl-5,6,11,12- tetrahydrochrysenes. J Med Chem 42(13):2456-2468

25. Glazier MG, Bowman MA (2001) A review of the evidence for the use of phytoestrogens as a replacement for traditional estrogen replacement therapy. Arch Intern Med 161(9):1161-1172

26. Sotoca AM, Bovee TFH, Brand W, Velikova N, Boeren S, Murk AJ, Vervoort J, Rietjens IMCM (2010) Superinduction of estrogen receptor mediated gene expression in luciferase based reporter gene assays is mediated by a post-transcriptional mechanism. J Steroid Biochem Mol Biol 122(4):204-211

27. Bovee TFH, Schoonen WGEJ, Hamers ARM, Bento MJ, Peijnenburg AACM (2008) Screening of synthetic and plantderived compounds for (anti)estrogenic and (anti)androgenic activities. Anal Bioanal Chem 390(4):1111-1119

28. Boué SM, Burow ME, Wiese TE, Shih BY, Elliott S, CarterWientjes CH, McLachlan JA, Bhatnagar D (2011) Estrogenic and antiestrogenic activities of phytoalexins from red kidney bean (Phaseolus vulgaris L.). J Agric Food Chem 59(1):112-120 